\title{
Corrosion resistance evaluation of boron-carbon coating on ASTM A-36 steel
}

\author{
A. Márquez-Herrera ${ }^{a, *}$ and J. Moreno-Palmerin ${ }^{b}$ \\ ${ }^{a}$ Departamento de Ingeniería Agrícola, División de Ciencias de la Vida, Campus Irapuato-Salamanca, \\ Universidad de Guanajuato, Irapuato, Guanajuato, México 36500. \\ *e-mail: amarquez@ugto.mx \\ ${ }^{b}$ Departamento de Minas, Metalurgía y Geología, División de Ingenierías, Campus Guanajuato, \\ Universidad de Guanajuato, Guanajuato, Guanajuato, México 36020.
}

Received 21 July 2021; accepted 2 September 2021

The ASTM A-36 steel is the main material used in the manufacture of products and parts for general construction and mechanical engineering purposes. In this work, the effect of boron-carbon coating on corrosion resistance and hardness of the steel ASTM A-36 is reported. A boriding thermochemical treatment was performed at $950{ }^{\circ} \mathrm{C}$ during $4 \mathrm{~h}$. Followed by, a carburizing process for $6 \mathrm{~h}$ at $930{ }^{\circ} \mathrm{C}$. The corrosion analysis was done by electrochemical impedance spectroscopy (EIS) polarization and Tafel technique, which employed a fused deposition modeling-based 3D printing electrochemical cell made of polylactic acid (PLA). A commercial platinum foil and a silver/silver chloride $(\mathrm{Ag} / \mathrm{AgCl})$ electrode with $3.5 \mathrm{M}$ potassium chloride electrode solution (Electrolyte) were employed as the counter and reference electrode, respectively. and area $1 \mathrm{~cm}^{2}$ of the sample was employed as the working electrode (WE). Optical microscopic analysis shows that boride phase grown on the treated surfaces has a shark-tooth morphology with a thickness of about $60 \mu \mathrm{m}$ in samples. The carburizing over boride layer promotes the conformation of coatings on the outermost layer of the samples with a thickness of about $17 \mu \mathrm{m}$. X-ray diffraction (XRD) spectrum shown only the formation of the iron diboride phase $\left(\mathrm{Fe}_{2} \mathrm{~B}\right)$. Results shows that boride samples have inferior corrosion resistance in comparison to virgin sample, but after carburizing, an outer layer is formed, with the hardness and corrosion resistance similar to the original sample.

Keywords: Corrosion; ASTM A-36; 3D printing; boride; carburizing.

DOI: https://doi.org/10.31349/RevMexFis.68.011001

\section{Introduction}

Surface hardening opens the possibility of developing materials with desired properties to solve engineering problems. This technique has been used mainly to improve

material hardness. Although there exists a great demand in the improvement on machine elements, it is also of enormous importance to improve industrial processes of the machine materials to corrosion and wear. In this regard, several thermochemical treatments have been proposed to enhance the mechanical properties of material surfaces subject to wear and corrosion. The improved hardness has been obtained by coating the metal using processes such as boriding [1-4]. In recent years, other alternatives such as the duplex coating $[5,6]$, and more particularly the combined surface hardening with boron and carbon $[6,7]$, appeared to be an excellent option for surface hardening. This process takes advantage of mass transfer phenomenon (diffusion) which cause the distribution of boron and carbon atoms in the material to change the chemical composition on the surface. The, processed metal surface increases its mechanical properties as hardness. Although this resulting property is often attractive, no studies based on the evaluation of corrosion resistance have been published in the literature. In this sense, the aim of this work is to evaluate the surface corrosion resistance of the ASTM A-36 steel by depositing a boron-carbon coating via boriding. Followed by carburizing technique. For this purpose, different characterization techniques were used to evaluate the hardness, microstructure, morphology, X-ray diffraction and corrosion properties of the boron-carbon layer on ASTM A-36 steel. Additionally, the evaluation of corrosion on samples was conducted by using a homemade 3Dprinted electrochemical cell.

\section{Experimental procedure}

$25.4 \mathrm{~mm}$ Dia. $\times 5 \mathrm{~mm}$ long ASTM A-36 steel, with chemical composition of $0.2 \% \mathrm{Cu}, 0.26 \% \mathrm{C}, 0.05 \% \mathrm{~S}, 0.75 \% \mathrm{Mn}$ and $0.04 \% \mathrm{P}$, was used as substrate. For sample B, the boriding process involved deposition of boron paste (consisting of 5 wt. $\% \mathrm{~B}_{4} \mathrm{C}$ powder, 5 wt. $\% \mathrm{KBF}_{4}$ as a flux and 90 wt.\% $\mathrm{SiC}$ as refractory material) on the steel substrate to form a layer of about $5 \mathrm{~mm}$ thick. The coated steel sample was then situated in a preheated muffle furnace at $950^{\circ} \mathrm{C}$ for $4 \mathrm{~h}$. For sample $\mathrm{BC}$, boriding was followed by the carbonizing process. The carbonizing treatment was conducted via the pack cementation method in a muffle furnace at $930^{\circ} \mathrm{C}$ for $6 \mathrm{~h}$ using charcoal powder. The cross-sectional view of the samples was observed by optical microscopy. Where the samples were processed by conventional metallographic and etching by using nital 3.5. To perform the hardness test, the ASTM E384 standard was used, and a load of $0.981 \mathrm{~N}$ was applied for $15 \mathrm{~s}$. Diffractograms were made using monochromatic radiation $\mathrm{CuK}_{\alpha}$ line (wavelength $1.5406 \AA$ ) controlled at 35 $\mathrm{kV}$ and $15 \mathrm{~mA}$ by Grazing incidence small angle X-ray scattering (GISAXS). The corrosion analysis was done by using 

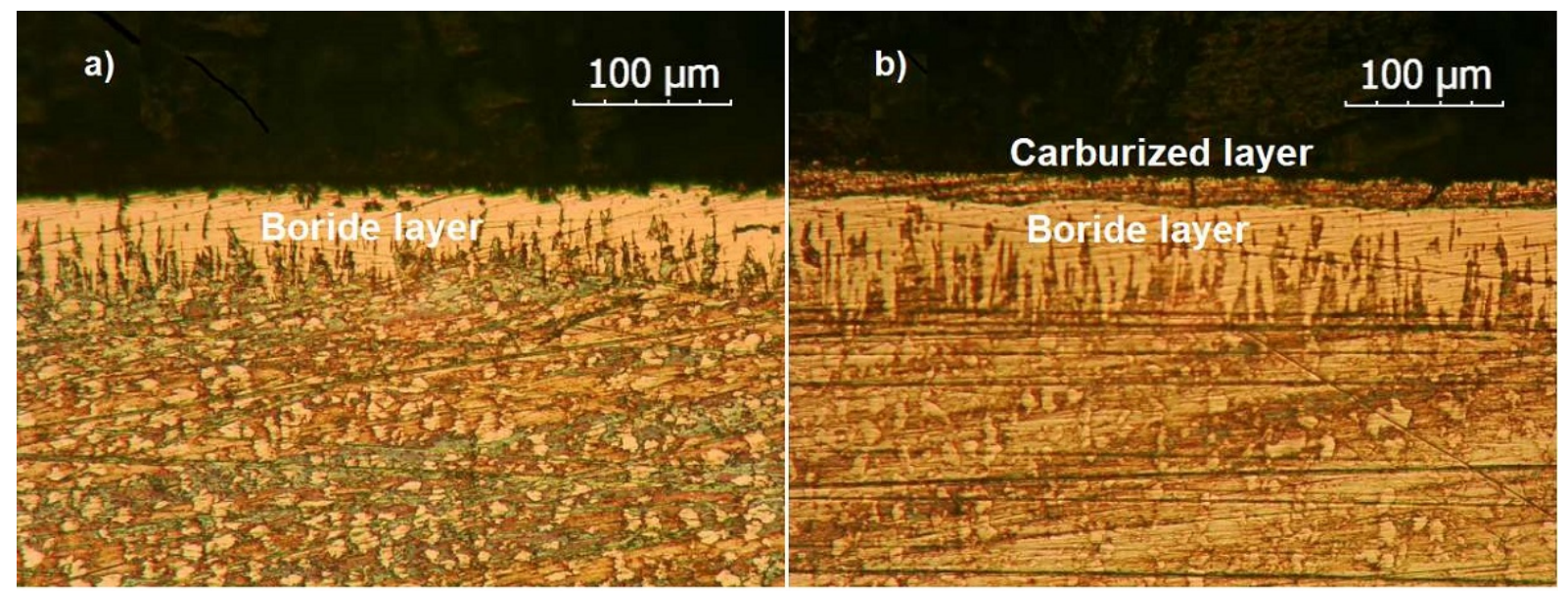

FIGURE 1. Microstructure of (a) boride and (b) borocarburized ASTM A-36 steel sample.

EIS and Tafel technique, employing a novel 3D-printed electrochemical cell from a commercially available composite of polylactic acid (PLA). Tafel and EIS test were carried out using $3.5 \mathrm{wt} . \% \mathrm{NaCl}$ solution in the electrochemical cell at room temperature. An open corrosion potential was applied during $60 \mathrm{~min}$. A sinusoidal alternating current signal of 10 $\mathrm{mV}$ and a sweep frequency from $1 \mathrm{MHz}$ to $50 \mathrm{mHz}$ were used for the EIS test. The Tafel polarization plots were obtained by performing a scan comprising $\pm 250 \mathrm{mV}$ vs. corrosion potential $\left(\mathrm{E}_{\text {corr }}\right)$ at a scanning speed of $0.5 \mathrm{mV} / \mathrm{s}$. Tafel curves were fitted to find both $\mathrm{I}_{\text {corr }}$ (corrosion current) and $\mathrm{E}_{\text {corr }}$. Further, the corrosion current was calculated from $\mathrm{I}_{\text {corr }}$ according to ASTM G102-89 standard. A minimum of 3 samples for each experiment were exposed to the tests and compared with untreated ASTM A-36 steel (sample V).

\section{Results and discussion}

The hardness of the ASTM A-36 steel before heat treatments (sample V) was about $162 \mathrm{HV}$. After the boride process, the

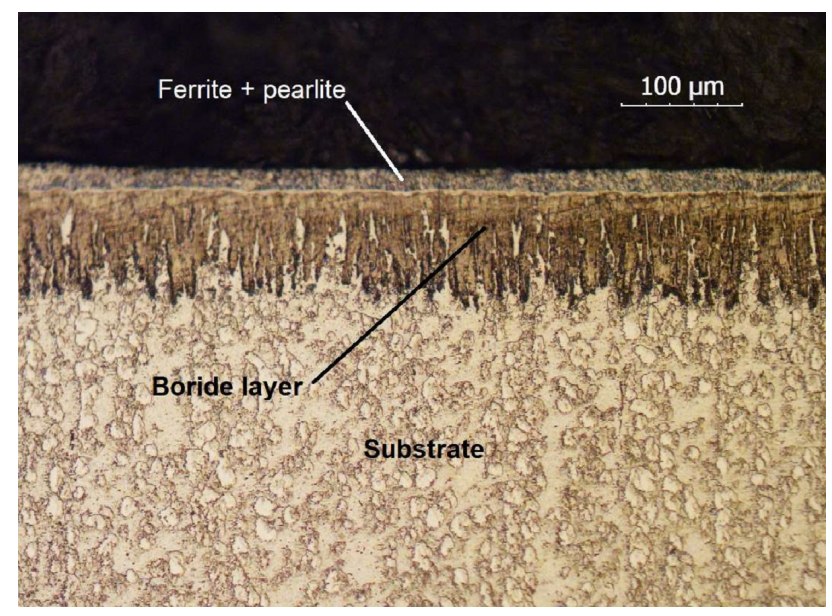

FIGURE 2. Microstructure of borocarburized ASTM A-36 steel sample. surface hardness of sample B was about $960 \mathrm{HV}$, whereas that of the sample BC was about $164 \mathrm{HV}$, similar to virgin sample.

The optical cross-sectional images of samples B and BC are shown in Fig. 1. The Optical microscopy analysis of the samples with the same cross-sectional area shows that boride coating composed on the surface of steels has a shark tooth morphology and a boride layer with a thickness of about 60 $\mu \mathrm{m}$ in both samples. Figure 1a) shows that the boride phase, obtained from the boriding process, on the surface of sample $\mathrm{B}$ is $\mathrm{Fe}_{2} \mathrm{~B}$ [4]. The carburizing after boriding promotes the formation of coatings on the outermost layer of the samples with a thickness of about $17 \mu \mathrm{m}$ over the boride layer (Fig. 1b)).

Metallographic analysis of the BC sample is shown in Fig. 2. It is well known that in a hypoeutectoid steel the equlibrium microstructure at room temperature consists of ferrite and pearlite [8], so that, as the hardness of the outer layer of the BC sample is similar to sample $\mathrm{V}$, it suggests that the outer layer is composed as a virgin sample, instead of $\mathrm{Fe}_{3} \mathrm{C}$ as mentioned by Lopez-Perrusquia et al. [9]. In this sense, Bhadeshia et al. [10] revealed a microhardness of about $1230 \mathrm{HV}$ in cementite, while Lopez-Perrusquia et al. [9] reported a hardness for cementite similar to an untreated sample as reported in this work. It suggests that his analysis may was not properly done.

The inner boride layer, shown in Fig. 2, was formed before the carburizing process and then it was displaced inwards by the carburizing treatment. The outer layer represents the dissolved carbon in the austenite during carburizing process. During this process, the carbon atoms diffuse through the boride layer to form austenite displacing the boron atoms, which at the same time diffuse depper into the material. Finally, it forms an outer layer of ferrite + pearlite, since it exhibits a similar hardness than sample V.

Figure 3 shows the X-ray diffraction patterns of samples $\mathrm{B}$ and BC. According to the 361332 card from ICDD's Powder Diffraction Files, the diffraction peak positions confirm that iron diboride $\left(\mathrm{Fe}_{2} \mathrm{~B}\right)$ phase on boride and borocarburized 


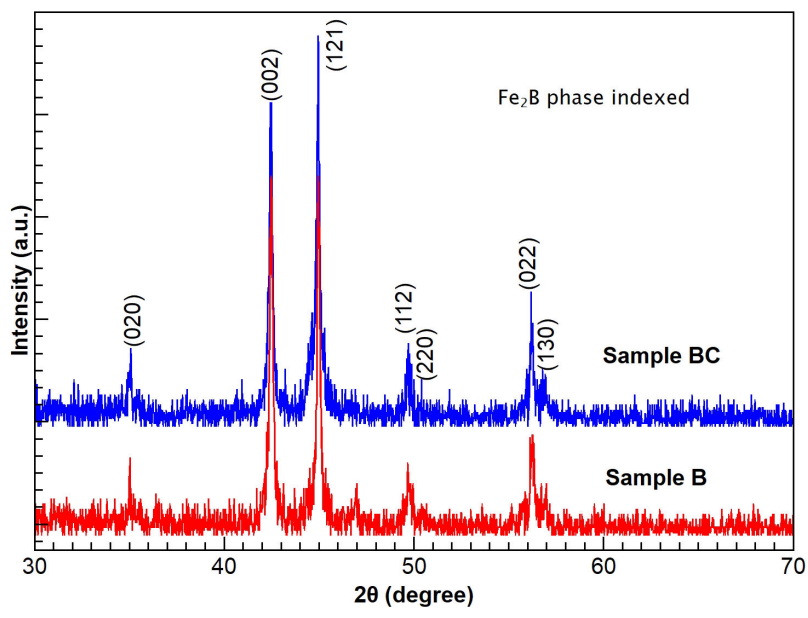

FIGURE 3.X-ray diffraction patterns of sample B and BC.

ASTM A-36 steel sample was all formed. Non-indexed peaks on diffractograms may correspond to noise, rust, or residues from the hardening process as shown in others works [11,12].

The X-ray diffraction spectrum corroborates that the boride phase on layer is formed of $\mathrm{Fe}_{2} \mathrm{~B}$ for both samples because there is a full compliance to the diffraction peak positions and the diffraction database. An important fact is that $\mathrm{X}$-ray diffraction patterns are clearly related with the tetragonal iron diboride phase which has lower brittlement than the secondary crystalline FeB phase. However, the proper identification of the outer layer in sample BC was not possible as its diffraction signal is not enough or it is inside the diffraction noise, and more work is needed.

The corrosion study was achieved by using our own 3Dprinted electrochemical cell, Fig. 4. The manufactured cell has a size of $100 \mathrm{~mm}$ length, $50 \mathrm{~mm}$ width and $50 \mathrm{~mm}$ height. The container has a volume of about $100 \mathrm{ml}$ that held the electrolyte solution, allowing to place $1 \mathrm{~cm}^{2}$ area of sample (WE). 3D printing allows to adapt the design of an electrode at the lowest possible price. As the counter electrode, a platinum foil of $0.1 \mathrm{~mm}$ thickness and $99.9 \%$ wt. purity, so reducing its price, was used. A commercial $\mathrm{Ag} / \mathrm{AgCl}$ reference electrode was employed to evaluate the electrode potentials. Virgin polytetrafluoroethylene (PTFE) gasket was used between the electrolyte solution and the working electrode to seal the cell. The first reported applications of fused deposition melting (FDM) in the electrochemical research include cells for spectro-electrochemistry [13], building reaction cells for water electrolysis [14], as well as the construction of electrochemical flow cells $[15,16], 3 \mathrm{D}$ printed electrodes [17], electrochemical cells to sensors [18], reference electrodes [19]. However the manufacture of an electrochemical cell serving as galvanic cell for materials has not been reported. It is important to mention that $3 \mathrm{D}$ printing allows the production of flexible and complex electrochemical cell designs which can be profiled, sized and potentially realized in a single, easy process, reducing materials, costs and work. Additionally, 3D printing allows the use of a)
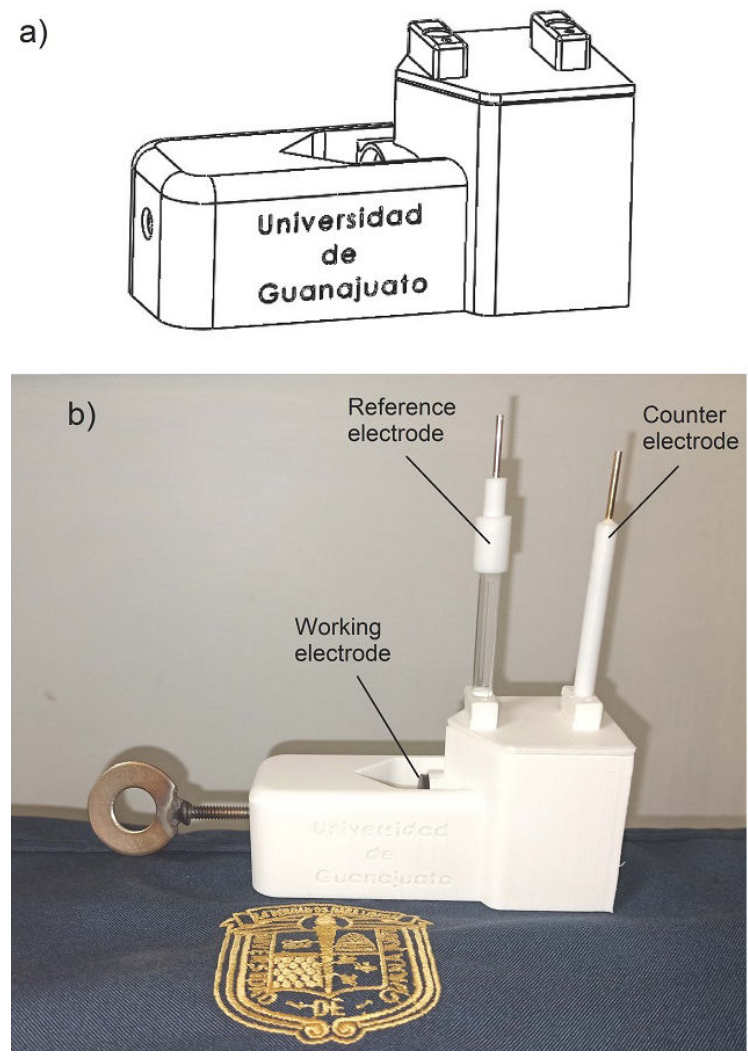

FIGURE 4. a) CAD model assembly for the electrochemical cell. b) Complete electrochemical design fabricated via 3D printing using polylactic acid (PLA) plastic.

other thermoplastic filaments. It is important to remark that a complete work about this cell is in process.

In this sense, Fig. 5 shows the electrochemical impedance (EIS) and Tafel polarization spectra obtained during the testing of samples $\mathrm{V}, \mathrm{B}$, and $\mathrm{BC}$ in $\mathrm{NaCl}$ aqueous solution.

As can be clearly seen from Fig. 5a), projection of the boride sample impedance ( $x$-axis) is similar than the borocarburized steel and higher than boride sample. As a first approximation, these results suggest that the boriding process over the steel provides a lower corrosion resistance than the virgin ASTM A-36 steel.

The inset in Fig. 5a) shows the improved equivalent electrical circuit for the samples. The model aimed to simulate the chemical behavior of the steel surface in the presence of $\mathrm{Cl}^{-}$ions. $\mathrm{R}_{\text {sol }}$ corresponds to the solution resistance and $\left(\mathrm{C}_{1} \mathrm{R}_{1}\right)\left(\mathrm{C}_{2} \mathrm{R}_{2}\right)\left(\mathrm{C}_{3} \mathrm{R}_{3}\right)$ to the resistance and capacitance of the substrates. The data fits with the equivalent electrical circuit is presented in Table I with a low relative standard error (RSE $<10 \%$ ).

The amount of resistances $\left(\mathrm{R}_{1}, \mathrm{R}_{2}\right.$, and $\left.\mathrm{R}_{3}\right)$ represents the polarization resistance, $\mathrm{R}_{p}$, of the sample. A higher value of $\mathrm{R}_{p}$ implies a better corrosion protection capability of the layer. It is important to note that for all the samples, $\mathrm{R}_{\text {sol }}$ was very similar due the same solution was used. Table I shows a greater charge transfer resistance of $1120.7 \Omega$ for sample $\mathrm{V}$ while samples B and BC have resistance equal to $781.3 \Omega$ 


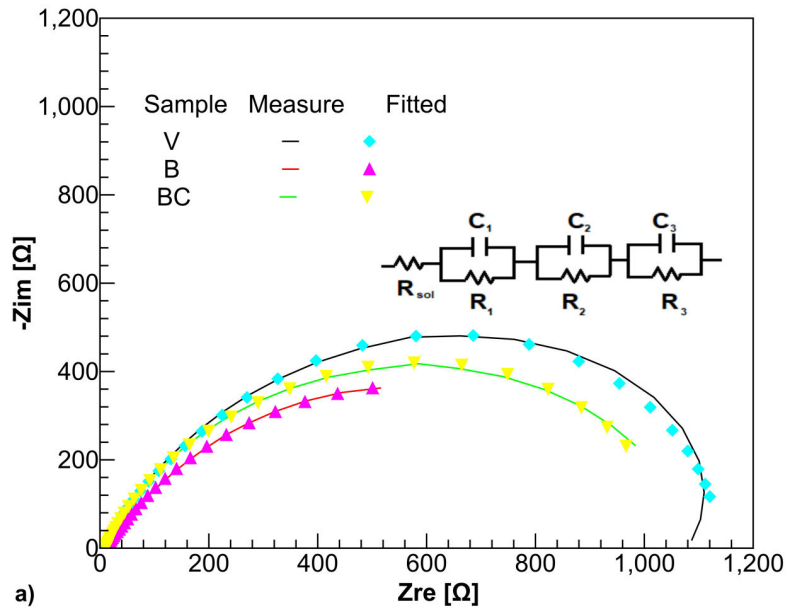

a)

FIGURE 5. a) EIS and b) polarization plots for samples $\mathrm{V}, \mathrm{B}$ and $\mathrm{BC}$ in $\mathrm{NaCl} 3.5 \%$ wt. solution. The inset represents the suggested equivalent circuit, $\mathrm{R}_{\text {sol }}\left(\mathrm{C}_{1} \mathrm{R}_{1}\right)\left(\mathrm{C}_{2} \mathrm{R}_{2}\right)\left(\mathrm{C}_{3} \mathrm{R}_{3}\right)$ on ASTM A-36 steel sample.

TABLE I. Parameters of proposed equivalent electric circuit.

\begin{tabular}{cccc}
\hline Parameter & Sample V & Sample B & Sample BC \\
\hline $\mathrm{R}_{\text {sol }}(\Omega)$ & 12.3 & 11.7 & 11.3 \\
$\mathrm{C}_{1}(\mu \mathrm{F})$ & 175.7 & 741.3 & 370.1 \\
$\mathrm{R}_{1}(\Omega)$ & 13.0 & 12.8 & 11.5 \\
$\mathrm{C}_{2}(\mu \mathrm{F})$ & 263.4 & 1811.0 & 603.3 \\
$\mathrm{R}_{2}(\Omega)$ & 135.2 & 85.4 & 129.6 \\
$\mathrm{C}_{3}(\mu \mathrm{F})$ & 366.6 & 3349.0 & 888.1 \\
$\mathrm{R}_{3}(\Omega)$ & 960.2 & 671.4 & 845.8 \\
$\mathrm{R}_{p}(\Omega)$ & 1108.4 & 769.6 & 986.9 \\
\hline
\end{tabular}

TABLE II. Values of corrosion current $\left(\mathrm{I}_{\text {corr }}\right)$ and corrosion potential $\left(\mathrm{E}_{\text {corr }}\right)$.

\begin{tabular}{cccc}
\hline Values & Sample V & Sample B & Sample BC \\
\hline $\mathrm{E}_{\text {corr }}(\mathrm{mV})$ & -673.7 & -648.0 & -694.6 \\
$\mathrm{I}_{\text {corr }}(\mu \mathrm{A})$ & 12.2 & 26.0 & 13.3 \\
\hline \hline
\end{tabular}

and $998.2 \Omega$, respectively. These results show that the boride sample has less resistance to corrosion than the untreated sample; however, its resistance increases after undergoing the carbonizing process to form the outer layer, as shown in Fig. 3.

Also, Fig. 5b) shows the Tafel polarization behavior where sample B and BC exhibits less negative corrosion potential related to sample V. Samples with more negative potential, $\mathrm{E}_{\text {corr }}$, can have some extra protection, acting as cathodic protection. In this case, the substrate, with a more negative potential, works as a sacrificial anode [20]. The values of corrosion potential $\left(\mathrm{E}_{\text {corr }}\right)$ and corrosion current $\left(\mathrm{I}_{\mathrm{corr}}\right)$ obtained from the Tafel polarization curves are shown in Table II. These values shows that the charge exchange activity, $\left(\mathrm{I}_{\text {corr }}\right)$, at the interface of the samples exposed to the boride process is higher than the virgin sample. This is manifested

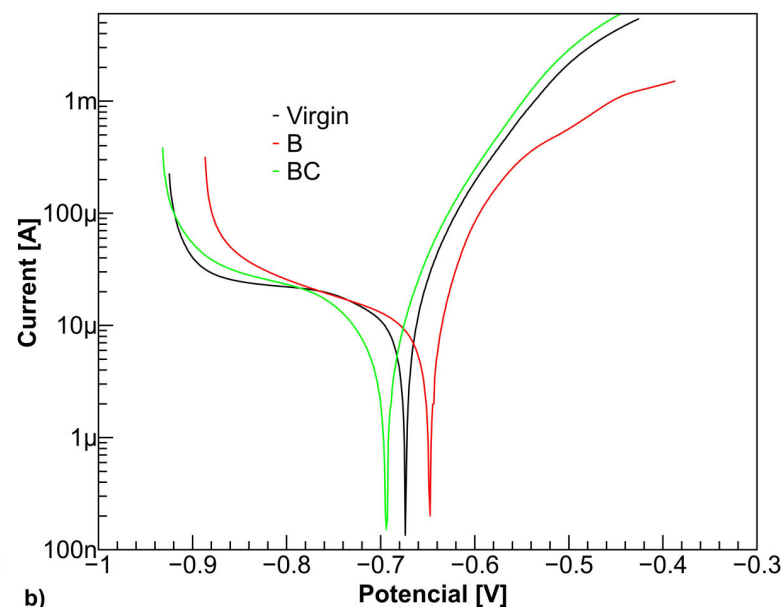

as an increment in the corrosion current, $\mathrm{I}_{\text {corr }}$. On the contrary, the sample BC shows a close corrosion current as the virgin sample, suggesting that the material of the outer layer is like the substrate. Thus, it could be partly inferred that during the boriding kinetics of our samples, resistance to corrosion decreases, and it increases after carburizing process because the outer layer is similar than substrate. It should be pointed out that the formation of this outer layer due to the boron-carbon coating process opens the possibility of modifying it through other techniques such as burnishing [21-23], heat treatment, etc., which could improve both its hardness and corrosion resistance.

When untreated ASTM A-36 steel is exposed to corrosion, aggressive $\mathrm{Cl}^{-}$ions cause corrosion on the steel. Consequently, $\mathrm{Fe}^{+2}$ ions are formed, and then react with $\mathrm{OH}^{-}$ ions producing rust [24]. Although, $\mathrm{Fe}_{2} \mathrm{~B}$ phase is a ceramic material with a high hardness [25] and high corrosion resistance [26]. It protects any surface against the attack of aggressive ions as $\mathrm{Cl}^{-}$ions, which are responsible for the steel corrosion. However, Fig. 5 shows that boride layer produces a lower corrosion resistance in the material. Despite some works $[27,28]$ reported that $\mathrm{Cl}^{-}$ions could penetrate through the cracks in the boride coating causing corrosion on substrate, Fig. 6 shows some saw tooth needles from substrate crossing the boride layer that reduce the corrosion protection of the boride layer by exposing the substrate directly to the electrolyte solution. Additionally, Fig. 5 shows how the corrosion potential $\left(\mathrm{E}_{\text {corr }}\right)$ of boride sample is less negative than virgin sample causing galvanic corrosion whereby the cathode $\left(\mathrm{Fe}_{2} \mathrm{~B}\right.$ layer) is protected, whereas the anode (substrate) is corroded [29]. Consequently, the rate of attack $\left(\mathrm{I}_{\text {corr }}\right)$ on the boride substrate is accelerated contrasted with the corrosion rate when the material is untreated as shown in Table II. As resistance corrosion of borocarburized sample is similar to virgin sample, it is possible that the outer layer is formed close to substrate composition and the $\mathrm{Cl}^{-}$ions attack the surface as in the virgin sample. 


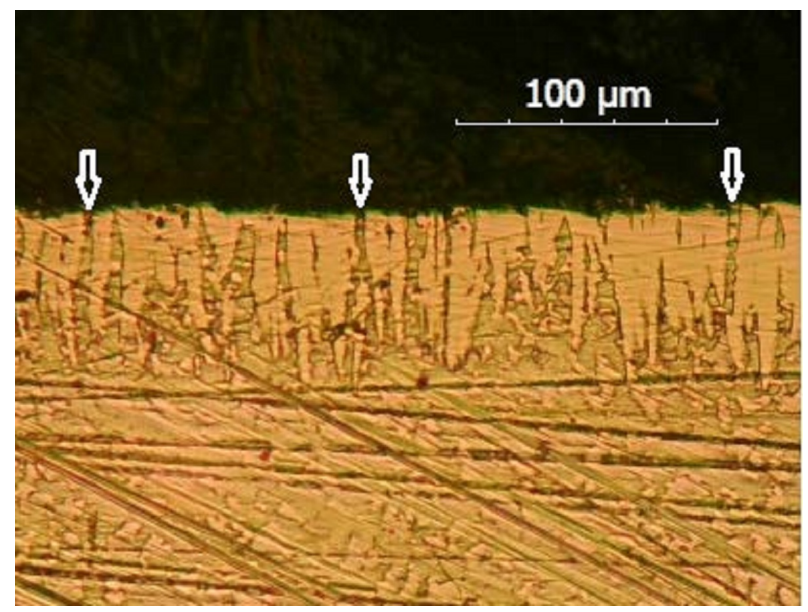

FIgURE 6. Microstructure of boride ASTM A-36 steel sample. Some saw tooth needles from substrate are indicated in figure.

\section{Conclusions}

Regarding the boride structure, it was verified by diffraction pattern analysis the formation of the $\mathrm{Fe}_{2} \mathrm{~B}$ phase. The re- sults shows that ASTM A-36 steel increases its hardness after the boriding process, however, in corrosive environments, it exhibits inferior corrosion resistance compared to untreated sample due to substrate exposure and maybe to galvanic corrosion process. Also, it is useful to mention that in the boride sample, after carburizing, an outer layer was formed whose hardness and corrosion resistance were similar to virgin sample. For boring material applications where corrosion is involved, it is important to consider the substrate needles because they could reduce corrosion resistance. Finally, the results shows the possibility of replacing commercial electrochemical cells with the homemade 3D printed cell without any compromise on quality at low cost.

\section{Acknowledgements}

The experimental work was supported by Laboratorio Nacional de Investigación y Desarrollo Tecnológico de Recubrimientos Avanzados of Cinvestav-UG.
1. Z. Nait-Abdellah, M. Keddam, and P Jurci, Simulation of boronizing kinetics of ASTM A36 steel with the alternative kinetic model and the integral method, Koroze a Ochrana Materiálu 65 (2021) 33, htts://doi.org/10.2478/ kom-2021-0004

2. J. L. Argüelles-Ojeda, A. Márquez-Herrera, A.L. SaldañaRobles, A. Saldaña-Robles, M.A. Corona-Rivera, and J. Moreno-Palmerin, Hardness optimization of boride diffusion layer on ASTM F-75 alloy using response surface methodology, Rev. Mex. de Fis. 63 (2017) 76.

3. I. A. Garmaeva, A. M. Guriev, T. G. Ivanova, M. A. Guriev, and S. G. Ivanov, Comparative study of saturating power boriding media of different composition, Letters on Materials 6 (2016) 262, htts://doi.org/10.22226/ 2410-3535-2016-4-262-265.

4. A. Márquez-Herrera, J. L. Fernandez-Muñoz, M. ZapataTorres, M. Melendez-Lira, and P. Cruz-Alcantar, $\mathrm{Fe} 2 \mathrm{~B}$ coating on ASTM A-36 steel surfaces and its evaluation of hardness and corrosion resistance, Surface and Coatings Technology 254 (2014) 433, htts://doi.org/10.1016/j. surfcoat.2014.07.001

5. C. A. Cuao-Moreu et al., Characterization of a duplex coating (boriding + sputter-deposited AlCrON) synthesized on an ASTM F-75 cobalt alloy, Thin Solid Films 712 (2020) 138318, htts://doi.org/10.1016/j.tsf.2020.138318.

6. M. Kulka, N. Makuch, P. Dziarski, D. Mikołajczak, and D. Przestacki, Gradient boride layers formed by diffusion carburizing and laser boriding, Optics and Lasers in Engineering 67 (2015) 163, htts://doi.org/10.1016/j. optlaseng.2014.11.015
7. M. Kulka, and A. Pertek, Gradient formation of boride layers by borocarburizing, Applied Surface Science 254 (2008) 5281, htts://doi.org/10.1016/j.apsusc.2008. 02.051

8. D. Neff, E. Vega, P. Dillmann, M. Descostes, L. Bellot-Gurlet, G. Béranger, 4-Contribution of iron archaeological artefacts to the estimation of average corrosion rates and the long-term corrosion mechanisms of low-carbon steel buried in soil (Woodhead Publishing, 2007) pp. 41-76, htts://doi.org/10. $1533 / 9781845693015.41$

9. N. López-Perrusquia, M.A. Donu-Ruiz, E.D. García-Bustos, M. Flores-Martínez, G.M. Urriolagoitia-Calderón, and C.R. Torres-San-Miguel, Duplex surface treatment on microalloy steels by dehydrated paste pack boriding and pack carburizing, Materials Letters 280 (2020) 128573, htts://doi.org/ $10.1016 /$ j.matlet.2020.128573

10. H. K. D. H. Bhadeshia, Cementite, International Materials Reviews 65 (2020) 1, htts://doi.org/10.1080/ 09506608.2018 .1560984

11. M. Ortiz-Domínguez et al., Modeling of the Growth Kinetics of Boride Layers in Powder-Pack Borided ASTM A36 Steel Based on Two Different Approaches, Advances in Materials Science and Engineering 2019 (2019) 5985617, htts://doi .org/ $10.1155 / 2019 / 5985617$

12. M. Ortiz-Domínguez et al., Characterization of Coatings Obtained by Dehydrated Paste-Pack Boriding Process Formed on AISI A36 Carbon and 304 Alloy Steels, Microscopy and Microanalysis 25 (2019) 2400, htts: / / doi .org/10.1017/ S143192761901273X

13. A. Vertova et al., 3D-printed photo-spectroelectrochemical devices for in situ and in operando X-ray absorption spectroscopy 
investigation, Journal of synchrotron radiation 23 (2016) 622, htts://doi.org/10.1107/S1600577515024480.

14. G. Chisholm, P. J. Kitson, N. D. Kirkaldy, L. G. Bloora, and L. Cronin, $3 D$ printed flow plates for the electrolysis of water, an economic and adaptable approach to device manufacture, Energy \& Environmental Science 7 (2014) 3026, htts : //doi.org/10.1039/C4EE01426J

15. G. W. Bishop et al., 3D-printed fluidic devices for nanoparticle preparation and flow-injection amperometry using integrated prussian blue nanoparticlemodified electrodes, Analytical chemistry 87 (2015) 5437, htts://doi.org/10. 1021/acs.analchem.5b00903

16. C. Ponce de Leona et al., The 3D printing of a polymeric electrochemical cell body and its characterisation, Chemical Engineering Transactions 41 (2014) 1, htts://doi.org/10. $3303 /$ CET1441001

17. E. Vanecková et al., UV/VIS spectroelectrochemistry with $3 D$ printed electrodes, Journal of Electroanalytical Chemistry 857 (2020) 113760, htts: / /doi .org/10.1016/j. jelechem.2019.113760

18. R.M. Cardoso et al., $3 D$ printing for electroanalysis: from multiuse electrochemical cells to sensors, Analytica Chimica Acta 1033 (2018) 49, htts : / doi .org/10.1016/j. aca.2018.06.021

19. B. Schmidt, D. King, and J. Kariuki, Designing and using 3Dprinted components that allow students to fabricate low-cost, adaptable, disposable, and reliable $\mathrm{Ag} / \mathrm{AgCl}$ reference electrodes, Journal of Chemical Education 95 (2018) 2076, htts : //doi.org/10.1021/acs.jchemed.8b00512.

20. S. Szabo, and I. Bakos, Cathodic protection with sacrificial anodes, Corrosion Reviews 24 (2006) 231, htts : / / doi . org/ $10.1515 /$ CORRREV.2006.24.3-4.231.
21. C. Prakash et al., Synthesis of functionalized TiO2-loaded HApcoating by ball-burnishing assisted electric discharge cladding process, Materials Letters 301 (2021) 130282, htts : / / doi. org/10.1016/j.matlet.2021.130282

22. J. L. Argüelles-Ojeda et al., Corrosion behavior of boride diffusion layer on CoCrMo alloy surface, Indian Journal of Engineering and Materials Sciences (IJEMS) 27 (2020) 87.

23. A. Saldaña-Robles et al., Influence of ball-burnishing on roughness, hardness and corrosion resistance of AISI 1045 steel, Surface and Coatings Technology 339 (2018) 191, htts: //doi.org/10.1016/j.surfcoat.2018.02.013

24. J. Ávila, and J. Genescá, Más allá de la herrumbre 1 (Fondo de Cultura Económica, 2013) pp. 23-56.

25. Y. Zhengang, L. Wenping, J. Yanlin, M. Qiang, D. Zheng, and Y. Haiyang, High Temperature Tribological Behavior of Borocarburized Layer on Q235 Steel, Materials Science 27 (2021) 42, htts://doi.org/10.5755/j02.ms.24682

26. E. Medvedovski, Advanced iron boride coatings to enhance corrosion resistance of steels in geothermal power generation, Advances in Applied Ceramics 119, 8 (2020) 462, htts: //doi.org/10.1080/17436753.2020.1830359

27. I. Campos-Silva et al., Evolution of boride layers during a diffusion annealing process, Surface and Coatings Technology 309 (2017) 155, htts://doi.org/10.1016/j. surfcoat.2016.11.054

28. Y. Kayali, and B. Anaturk, Investigation of electrochemical corrosion behavior in a $3.5 \mathrm{wt} . \% \mathrm{NaCl}$ solution of boronized dual-phase steel. Materials \& Design 46 (2013) 776, htts: //doi.org/10.1016/j.matdes.2012.11.040

29. P. Pedeferri, Corrosion science and engineering (Springer, 2018) pp. 183-206, htt://doi.org/10.1007/ 978-3-319-97625-9_10 